\title{
Status of Some Basic Antioxidants in Pre- and Postmalaria Treatment in Children
}

\author{
Adejumoke Idowu Ayede ${ }^{1} \quad$ Banke Lois Amoo ${ }^{2}$ John Ibhagbemien Anetor ${ }^{2}$ Adesegun S. Adeola ${ }^{2}$ \\ ${ }^{1}$ Department of Paediatrics, College of Medicine, University of Ibadan \\ and University College Hospital (UCH), Ibadan, Nigeria \\ 2 Department of Chemical Pathology, University of Ibadan, Ibadan, Nigeria \\ Address for correspondence John Ibhagbemien Anetor, PhD, FIBMS \\ (UK), FACN, ERT, FRSC (UK), Department of Chemical Pathology, \\ College of Medicine, University of Ibadan, University College Hospital \\ J Child Sci 2018;8:e31-e35. \\ (UCH), Campus, Ibadan, Nigeria (e-mail: johnanetor@gmail.com).
}

\begin{abstract}
Keywords

- antioxidant

- children

- free radicals

- malaria parasitemia

- oxidative stress

Malaria is the most common tropical disease to which infants and children are the most susceptible. It is caused by Plasmodium species and is associated with oxidative stress, which has an effect on body antioxidants. The relationship between the degree of parasitemia and copper $(\mathrm{Cu})$, zinc $(\mathrm{Zn})$, and uric acid was evaluated in this study.

Seventy children (mean age: $7.80 \pm 0.38$ years) microscopically diagnosed positive for malaria parasite were selected. Fifty-six apparently healthy children (mean age: $6.68 \pm 0.48$ years) served as the control group. The malaria group was classified into pretreatment and posttreatment groups. The pretreatment group was also subgrouped based on parasitemia into four as follows: group A, group B, group C, and group D. Serum $\mathrm{Cu}$ and $\mathrm{Zn}$ were studied. Uric acid, an abundant endogenous metabolic antioxidant, was also determined.

The serum levels of $\mathrm{Cu}$ and $\mathrm{Zn}$ were significantly lower in pretreatment malaria patients compared with control. Uric acid level was slightly raised in the malaria patients but not significant $(p>0.05)$. In the posttreatment malaria patient group, serum uric acid and $\mathrm{Cu}$ levels were significantly raised compared with control $(p=0.008)$. Also, serum $\mathrm{Cu}$ and uric acid were significantly higher in the malaria posttreatment compared with the pretreatment group. Serum $\mathrm{Zn}$ level though higher in the posttreatment group compared with the pretreatment group was not significantly different $(p>0.05)$. The result showed a negative correlation between serum Cu level and parasitemia, and serum Zn level and parasitemia while that of uric acid and parasitemia was positively correlated but none of these were significantly correlated with parasitemia.

The observed changes in $\mathrm{Cu}, \mathrm{Zn}$, and uric acid levels in this study could be a reflection of progressive upregulation of the antioxidant system to combat the associated oxidative stress in this condition.
\end{abstract}

\section{Introduction}

Malaria is one of the most important parasitic diseases worldwide and approximately 250 million people are infected every year and up to one million die, most of them being young children and pregnant women. ${ }^{1}$ Infants are more vulnerable to malaria from the age of approximately 3 months when immunity acquired from the mothers wears off. The disease is caused by a parasite of the genus

received

September 11, 2017 accepted after revision March 14, 2018
DOI https://doi.org/

10.1055/s-0038-1642065. ISSN 2474-5871.
Plasmodium that is transmitted by female Anopheles mosquitoes. Malaria is characterized by the typical clinical features, such as fever, shivers, headache, and myalgia. These typical malaria symptoms-often referred to as acute or febrile malaria-are especially seen in young children and nonimmune adults.

The malarial infection has the ability to activate the immune system, which causes the release of reactive oxygen species (ROS) with the potency of inducing oxidative
Copyright (c) 2018 Georg Thieme Verlag License terms KG Stuttgart · New York 
damage and cell destruction. ${ }^{2}$ Free radicals (such as hydroxyl radical and superoxide anion), which are generated during the malaria episode will react rapidly and nonspecifically with most biological molecules. ${ }^{3}$ Thus, there are complex antioxidant metabolites present in organisms that work together to prevent oxidative damage to cellular components. ${ }^{4}$ Generally, antioxidants may either prevent or they may remove ROS formed prior their damage to cellular components. Though these may not be totally removed due to their useful functions in the cells but rather keep at an optimal level. ${ }^{5}$ There are different antioxidants present in the body fluids at a wide range of concentrations, for instance, uric acid (UA), which is more evenly distributed. Also, zinc $(\mathrm{Zn})$ and copper $(\mathrm{Cu})$, the antioxidant nutrients, are required by the antioxidant enzymes. Zinc plays a key role in immune competence ${ }^{6}$ and also in the linear growth of children. ${ }^{7}$ Copper is an important component of superoxide dismutase (SOD), an antioxidant enzyme that fights against the effect of ROS. ${ }^{8} \mathrm{UA}$ is an antioxidant oxypurine produced from xanthine by the enzyme xanthine oxidase and is an intermediate product of purine metabolism. ${ }^{9}$ In almost all land animals, urate oxidase has the ability to further catalyze the oxidation of UA to allantoin, while in humans UA is not further broken down. ${ }^{10,11} \mathrm{UA}$ has the highest concentration of any blood antioxidant ${ }^{12}$ and provides over half of the total antioxidant capacity of human serum. ${ }^{13}$ The antioxidant activities of UA are complex assumed that it does not react with some oxidants, such as superoxide, but does act against peroxynitrite, ${ }^{14}$ peroxides, and hypochlorous acid..$^{9}$ Introduction of UA in animal studies that investigated diseases accelerated by oxidative stress prevents the disease or reduces it. ${ }^{15}$ This finding was supported by UA antioxidant mechanism. ${ }^{16}$

\section{Materials and Methods}

\section{Study Site and Population}

Ethical approval was obtained from the University of Ibadan (UI)/University College Hospital (UCH) Ethical Committee before the commencement of the study. A written consent was obtained from the parents or guardians who agreed to participate and provide useful information about their children. The study was conducted at $\mathrm{UCH}$, from May to August 2012 in Ibadan, Oyo State. Malaria is hyperendemic, with transmission peaking during the rainy season (June, July, and September). The hospital has a pediatrics unit and malaria research section where the children were examined. One hundred twenty-seven children aged 2 to 15 years were enrolled into the study.

\section{Inclusion and Exclusion Criteria}

Eligibility criteria were:

1. Children who visited UCH for malaria treatment.

2. Children within the age range of 2 to 15 years.

3. Parental consent for the child's participation.

4. Patients who did not receive antimalarial treatment before enrolment.

\section{Exclusion Criteria}

The exclusion criteria were:

1. Children below age 2 years.

2. Children above 15 years.

3. Children presenting with other illnesses.

\section{Blood Collection}

Blood samples were collected by finger prick for $P$. falciparum test. Three milliliters of blood was collected from each participant by venipuncture and dispensed into plain metal-free bottles. The samples were centrifuged at 5,000 rpm for 10 minutes and the supernatant (serum) was separated with a pipette and stored at $-20^{\circ} \mathrm{C}$ until analysis of serum concentrations of $\mathrm{Cu}, \mathrm{Zn}$, and UA was done. The process was performed before and after treatment in children with conformed $P$. falciparum infection and once in uninfected subjects (control)

\section{Confirmation of Malaria Parasite}

Malaria thick and thin films were prepared by finger prick and the thin film was fixed with ethanol. Blood slides were stained with $5 \%$ Giemsa stain. The asexual parasites densities were estimated by counting parasites against 200 white blood cells, assuming a standard leukocyte count of 8,000 per $\mu \mathrm{L} .{ }^{17}$ Parasites densities were classified into four groups: A (parasite density $<1,000$ per $\mu \mathrm{L}$ ); B (parasite density $<2,000$ per $\mu \mathrm{L}$ ); C (parasite density $<10,000$ per $\mu \mathrm{L}$ ); and $\mathrm{D}$ (parasite density $>100,000$ per $\mu \mathrm{L}$ ).

\section{Drug Administration}

Artesunate-amodiaquine was given orally to all children for 3 consecutive days according to their body weight. They had initial and day 3 follow-up evaluation.

\section{Determination of Serum Uric Acid by Spectrophotometric Technique}

- In $3 \mathrm{~mL}$ centrifuge tubes labeled standard, blank, and unknown, $0.2 \mathrm{~mL}$ working UA standard, water, and unknown sera were prepared, respectively.

- Trisodium phosphate reagent $(0.2 \mathrm{~mL})$ was added to each; mixed and left for 5 minutes. This alkaline treatment destroyed any ascorbic acid that was in the sample, a nonurate chromogen.

- Phosphotungstic acid $(0.6 \mathrm{~mL})$ was added to the solution, mixed well, and centrifuged for 5 minutes.

- The supernatant fluid $(0.5 \mathrm{~mL})$ was transferred to a $12 \times 75 \mathrm{~mm}$ square cuvet of $10-\mathrm{mm}$ light path.

- Phosphotungstic acid $(0.2 \mathrm{~mL})$ and $1.5 \mathrm{~mL}$ of carbon-ureatriethanolamine (CUTE) reagent were added and mixed well by inversion.

- After 20 minutes, the absorbance of the sample against the blank at 680 to $700 \mathrm{~nm}$ was read.

- Calculation:

$\mathrm{Au} / \mathrm{As} \times 5.0=\mathrm{mg} / \mathrm{dL}$ UA $(\mathrm{Au}=$ absorbance of $\mathrm{UA} ; \mathrm{As}=$ absorbance of standard). 


\section{Determination of Serum Copper and Zinc by Atomic Absorption Spectrophotometry Technique}

The frozen serum samples were thawed and brought to room temperature after which they were prepared for analysis. The samples were deproteinized with $2 \mathrm{M}$ hydrochloric acid $(\mathrm{HCl})(1: 3)$. The digested samples were then centrifuged at $1,163 \times g$ for 5 minutes and the resulting supernatant was aspirated into the atomic absorption spectrophotometry (AAS). Three working standard solutions in parts per million (ppm) were prepared for each trace metal.

\section{Statistical Methods}

The data obtained from this study were subjected to statistical analysis using SPSS version 17.0 and Microsoft Excel Office. The descriptive statistics such as frequency, mean,

Table 1 Background characteristics

\begin{tabular}{|l|l|l|l|}
\hline & Control & Pretreatment & Posttreatment \\
\hline Variable & Mean \pm SEM & Mean \pm SEM & Mean \pm SEM \\
\hline Age (y) & $6.64 \pm 0.48$ & $7.87 \pm 0.37$ & $8.14 \pm 0.45$ \\
\hline $\begin{array}{l}\text { Weight } \\
(\mathrm{kg})\end{array}$ & $19.77 \pm 1.29$ & $22.83 \pm 1.42$ & $24.48 \pm 2.06$ \\
\hline $\begin{array}{l}\text { Height } \\
(\mathrm{cm})\end{array}$ & $111.57 \pm 3.09$ & $121.25 \pm 2.26$ & $123.55 \pm 2.63$ \\
\hline Sex & $N(\%)$ & $N(\%)$ & $N(\%)$ \\
\hline Male & $26(49.06)$ & $36(52.17)$ & $23(45.10)$ \\
\hline Female & $27(50.94)$ & $33(47.83)$ & $28(54.90)$ \\
\hline
\end{tabular}

Abbreviation: SEM, Standard error of mean. and standard error of mean (SEM) of sex, age, weight, and height, and the biochemical profile for the study groups were computed. Student's $t$-test (independent and paired) and analysis of variance (ANOVA) were used to compare means among variables. Correlation between serum $\mathrm{Cu}$ level and parasitemia, serum $\mathrm{Zn}$ level and parasitemia, and UA and parasitemia were examined using Pearson's product moment correlation. Results were considered significant at $p$-value of $<5 \%$.

\section{Results}

The background characteristics of patients who participated in the study are presented in -Table $\mathbf{1}$.

The levels of $\mathrm{Cu}$ and $\mathrm{Zn}$ were significantly lower in the pretreatment group compared with control $(p<0.05)$. While UA was not significantly different (-Table 2 ).

Parasitemia level was grouped into four and each group was compared with control. In group $\mathrm{A}, \mathrm{Cu}$ and $\mathrm{Zn}$ were significantly lower compared with control $(p<0.05)$, while UA was not significantly different $(p>0.05)$ (-Table 3 ).

Similarly, in group B, Cu and $\mathrm{Zn}$ were significantly lower compared with control $(p<0.05)$. UA was significantly higher compared with control $(p<0.05)$ ( - Table 3 ).

Copper and $\mathrm{Zn}$ were significantly lower in group C compared with control $(p<0.05)$. UA was higher than in control; however, it was not statistically significant $(p=0.056)$ (-Table 3).

In group $\mathrm{D}, \mathrm{Cu}$ and $\mathrm{Zn}$ were significantly lower compared with control $(p<0.05)$. Meanwhile, UA was higher in patients compared with control but not significant (-Table 3 ).

Table 2 Copper, zinc, and uric acid in malaria pretreatment compared with control

\begin{tabular}{|l|l|l|l|l|}
\hline Variables & $\begin{array}{l}\text { Case }(\boldsymbol{n}=70) \\
\text { Mean } \pm \text { SEM }\end{array}$ & $\begin{array}{l}\text { Control }(\boldsymbol{n}=56) \\
\text { Mean } \pm \text { SEM }\end{array}$ & $\boldsymbol{t}$-Value \\
\hline Cu $(\mu \mathrm{g} / \mathrm{dL})$ & $82.46 \pm 1.30$ & $128.15 \pm 1.30$ & 24.512 & $<0.05^{\mathrm{a}}$ \\
\hline Zn $(\mu \mathrm{g} / \mathrm{dL})$ & $85.90 \pm 8.10$ & $109.86 \pm 1.84$ & 2.600 & $<0.05^{\mathrm{a}}$ \\
\hline Uric acid $(\mathrm{mg} / \mathrm{dL})$ & $6.94 \pm 0.35$ & $5.6 \pm 0.35$ & 2.595 & 0.110 \\
\hline
\end{tabular}

Abbreviation: SEM, standard error of mean.

${ }^{a}$ Mean values are significantly different compared with control $(p<0.05)$.

Table 3 Zinc, Copper, and uric acid in four groups of parasitemia compared with control

\begin{tabular}{|l|l|l|l|l|l|}
\hline Variables & $\begin{array}{l}\text { Control } \\
(\boldsymbol{n}=56) \\
\text { Mean } \pm \text { SEM }\end{array}$ & $\begin{array}{l}\text { Parasitemia } \\
\text { group A } \\
(\mathrm{pd}<1,000 \\
\text { per } \mu \mathrm{L}) \\
(\boldsymbol{n}=11) \\
\text { Mean } \pm \text { SEM }\end{array}$ & $\begin{array}{l}\text { Parasitemia } \\
\text { group B } \\
(\mathrm{pd} 1,000-<2,000 \\
\text { per } \mu \mathrm{L}) \\
(\boldsymbol{n}=30) \\
\text { Mean } \pm \text { SEM }\end{array}$ & $\begin{array}{l}\text { Parasitemia group C } \\
(\mathrm{pd} 2000-<10,000 \\
\text { per } \mu \mathrm{L}) \\
(\boldsymbol{n}=22) \\
\text { Mean } \pm \text { SEM }\end{array}$ & $\begin{array}{l}\text { Parasitemia group D } \\
(\mathrm{pd} 10,000-<100,000 \\
\text { per } \mu \mathrm{L}) \\
(\boldsymbol{n}=5) \\
\text { Mean } \pm \text { SEM }\end{array}$ \\
\hline $\mathrm{Cu}(\mu \mathrm{g} / \mathrm{dL})$ & $128.15 \pm 9.68$ & $82.25 \pm 2.65^{\mathrm{a}}$ & $81.93 \pm 2.20^{\mathrm{a}}$ & $81.84 \pm 2.33^{\mathrm{a}}$ & $88.14 \pm 5.22^{\mathrm{a}}$ \\
\hline Zn $(\mu \mathrm{g} / \mathrm{dL})$ & $109.86 \pm 1.85$ & $71.29 \pm 2.14^{\mathrm{a}}$ & $80.34 \pm 2.18^{\mathrm{a}}$ & $77.76 \pm 2.36^{\mathrm{a}}$ & $79.21 \pm 2.80^{\mathrm{a}}$ \\
\hline $\begin{array}{l}\text { Uric acid } \\
(\mathrm{g} / \mathrm{dL})\end{array}$ & $5.63 \pm 0.35$ & $5.45 \pm 0.50$ & $7.28 \pm 0.63^{\mathrm{a}}$ & $6.95 \pm 0.62$ & $6.88 \pm 0.90$ \\
\hline
\end{tabular}

Abbreviations: pd, parasite density; SEM, standard error of mean.

${ }^{a}$ Mean values are significantly different compared with control $(p<0.05)$. 
To evaluate the effect of the treatment on parasitemia and its outcomes on the parameters, pre- and posttreatments were compared. Copper and UA were significantly increased in posttreatment compared with pretreatment $(p<0.05)$ (-Table 4).

All the three groups were compared to assess the effect of the intervention on malaria patients compared with apparently healthy controls. In these groups, $\mathrm{Cu}$ and UA were significantly different $(p<0.05)$ while $\mathrm{Zn}$ was not $(p>0.05)$ (-Table 4).

A negative correlation existed in this study between parasitemia and pretreatment $\mathrm{Cu}$ level, and also between parasitemia and pretreatment $\mathrm{Zn}$ level. In contrast, the relationship between parasitemia and UA was positive. These three relationships were very weak (- Table $\mathbf{5}$ ).

\section{Discussion}

This study showed that the serum Zn levels in patients varied in all the four categories of parasitemia levels. This slight decrease of serum $\mathrm{Zn}$ in these malaria-infected children may be attributed to increased consumption of $\mathrm{Zn}$ resulting from the enhanced production of tumor necrosis factor and other free radicals generated in the course of increasing parasitemia. It was documented by Onyesom et $\mathrm{al}^{18}{ }^{18}$ that severe malaria enhances the production of free radicals. It has been suggested that lowered $\mathrm{Zn}$ level is mediated by exaggerated production of free radicals and may reflect a normal protective mechanism. In addition to increased utilization of $\mathrm{Zn}$ by free radicals and oxidants, another plausible explanation for lower $\mathrm{Zn}$ levels in malaria can be preexisting $\mathrm{Zn}$ deficiency making the child more susceptible to malaria due to impaired immunity. ${ }^{19,20}$ This implies that serum $\mathrm{Zn}$ tended to decline with increasing malaria parasitemia. It was reported by Veenemans et $\mathrm{al}^{21}$ that there was a reduction in the episodes of malaria parasitemia in malaria patients on $\mathrm{Zn}$ supplement, suggesting that $\mathrm{Zn}$ might protect against severe forms of malaria. ${ }^{20}$ Although most often, serum $\mathrm{Zn}$ is low in malaria episodes in children, this was recovered after the completion of the treatment ( 72 hours). ${ }^{22}$ This suggests that low serum concentration in acute malaria infection most likely reflects the redistribution of blood $\mathrm{Zn}$ to other organs during the acute phase response.

In this study, serum Cu was significantly lower in malaria patients compared with the control group. This is in contrast to Saad et al's study ${ }^{23}$ that reported that serum $\mathrm{Cu}$ is most often raised as a component of ceruloplasmin, an acute phase reactant and antioxidant. Copper is also a component of the potent cytosolic antioxidant $\mathrm{Cu}-\mathrm{Zn}$ SOD ( $\mathrm{Cu}-\mathrm{Zn}$ SOD). The reduced $\mathrm{Cu}$ in this study could be to scavenge the oxidant released by immune cells and in so doing prevented the host and lessened the oxidative effect of parasitemia.

Uric acid was slightly higher in pretreatment but not statistically different as compared with control. In addition, this was statistically significant at posttreatment. UA is a metabolic or endogenous antioxidant. The UA pool appears to expand to contend with the body burden of oxidants as an adaptive response. The elevated urate level in malaria patients could indicate an adaptive response or mechanism against the toxins released by the immune cells against the parasites. This is in line with earlier reports, of raised serum UA concentration as a result of a physiologic response to oxidative stress, providing a counterregulatory increase in antioxidant defences. ${ }^{24,25}$ According to Lopera-Mesa et al, ${ }^{26}$ UA may be a consistent and reliable biomarker of significant generation of oxidants in malaria. UA also acts as a repair agent of oxidative damage to DNA bases, ${ }^{24}$ this may be another reason why UA was elevated in malaria patients after the treatment. In addition, in posttreatment, serum UA

Table 4 Copper, zinc, and uric acid in pre- and posttreatment of malaria and control

\begin{tabular}{|l|l|l|l|}
\hline Variables & $\begin{array}{l}\text { Control } \\
(\boldsymbol{n}=\mathbf{5 6}) \\
\text { Mean } \pm \text { SEM }\end{array}$ & $\begin{array}{l}\text { Pretreatment } \\
(\boldsymbol{n}=\mathbf{7 0}) \\
\text { Mean } \pm \text { SEM }\end{array}$ & $\begin{array}{l}\text { Posttreatment } \\
(\boldsymbol{n}=\mathbf{5 0}) \\
\text { Mean } \pm \text { SEM }\end{array}$ \\
\hline $\mathrm{Cu}(\mu \mathrm{g} / \mathrm{dL})$ & $128.15 \pm 9.68$ & $82.46 \pm 1.30$ & $114.78 \pm 10.3^{\mathrm{a}}$ \\
\hline $\mathrm{Zn}(\mu \mathrm{g} / \mathrm{dL})$ & $109.86 \pm 1.85$ & $85.90 \pm 8.10$ & $108.87 \pm 15.50$ \\
\hline Uric acid $(\mathrm{g} / \mathrm{dL})$ & $5.63 \pm 0.35$ & $6.94 \pm 0.35$ & $8.77 \pm 0.56^{\mathrm{a}, \mathrm{b}}$ \\
\hline
\end{tabular}

Abbreviation: SEM, standard error of mean.

${ }^{\mathrm{a}}$ Mean values are significantly different in posttreatment compared with pretreatment $(p<0.05)$.

${ }^{b}$ Mean values are significantly different in posttreatment compared with control $(p<0.05)$.

Table 5 Correlation of copper, zinc, and uric acid with parasitemia in the pretreatment group

\begin{tabular}{|l|l|l|l|l|}
\hline & Parasite & Pretreatment & Pretreatment & Pretreatment \\
\hline Variable & Count & Copper & Zinc & Uric acid \\
\hline Pearson's correlation & 1.000 & -0.161 & -0.155 & 0.166 \\
\hline$p$-Value & & 0.223 & 0.242 & 0.380 \\
\hline
\end{tabular}


was higher than in pretreatment probably due to oxidative stress induced by the drug.

\section{Conclusion}

The study revealed low levels of $\mathrm{Cu}$ and $\mathrm{Zn}$ in the pretreatment phase, which may at least in part suggest depressed antioxidant level as these micronutrients are component of the antioxidant system ( $\mathrm{Cu}-\mathrm{Zn}$ SOD). The raised levels in the posttreatment phase may imply improved antioxidant status.

\section{Conflict of Interest}

None.

\section{References}

1 Jean-Philippe S. (2005). Malaria: malaria. Available at: http//www. malariatest.com/malaria.html

2 Osioma E, Omoghene O. Total antioxidant capacity in serum of Plasmodium falciparum malarial infected patients receiving artemisinin-based combination therapy Onyesom I. Am J Med Med Sci 2012;2(02):1-3

3 Jomova K, Valko M. Advances in metal-induced oxidative stress and human disease. Toxicology 2011;283(2-3):65-87

4 Morgan MJ, Liu ZG. Crosstalk of reactive oxygen species and NF-KB signaling. Cell Res 2011;21(01):103-115

5 Dickinson BC, Chang CJ. Chemistry and biology of reactive oxygen species in signaling or stress responses. Nat Chem Biol 2011;7 (08):504-511

6 van Veldhuisen DJ, Ponikowski P, van der Meer P, et al; EFFECT-HF Investigators. Effect of ferric carboxymaltose on exercise capacity in patients with chronic heart failure and iron deficiency. Circulation 2017;136(15):1374-1383

7 Adriani M, Wirjatmadi B. The effect of adding zinc to vitamin A on IGF-1, bone age and linear growth in stunted children. J Trace Elem Med Biol 2014;28(04):431-435

8 Larson LM, Yousafzai AK. A meta-analysis of nutrition interventions on mental development of children under-two in low- and middle-income countries. Matern Child Nutr 2017;13(01):xx

9 Burckhardt G. Drug transport by organic anion transporters (OATs). Pharmacol Ther 2012;136(01):106-130

10 Schauer C, Janko C, Munoz LE, et al. Aggregated neutrophil extracellular traps limit inflammation by degrading cytokines and chemokines. Nat Med 2014;20(05):511-517

11 Feig DI, Kang DH, Johnson RJ. Uric acid and cardiovascular risk. N Engl J Med 2008;359(17):1811-1821
12 Bartoli F, Crocamo C, Mazza MG, Clerici M, Carrà G. Uric acid levels in subjects with bipolar disorder: a comparative meta-analysis. J Psychiatr Res 2016;81:133-139

13 Gebretsadik G, Seifu D, Yimer G, Menon MKC. The non-enzymatic antioxidant and level of oxidative stress of tuberculosis patients in selected treatment center in Addis Ababa, Ethiopia. J Tuberculosis Res 2015;3(03):58786

14 Rahal A, Kumar A, Singh V, et al. Oxidative stress, prooxidants, and antioxidants: the interplay. BioMed Res Int 2014;2014: 761264

15 Vassalle C, Mazzone A, Sabatino L, Carpeggiani C. Uric acid for cardiovascular risk: Dr. Jekyll or Mr. Hide? Diseases 2016;4 (01):12

16 Sautin YY, Johnson RJ. Uric acid: the oxidant-antioxidant paradox. Nucleosides Nucleotides Nucleic Acids 2008;27(06):608-619

17 Trape JF. Rapid evaluation of malaria parasite density and standardization of thick smear examination for epidemiological investigations. Trans R Soc Trop Med Hyg 1985;79(02):181-184

18 Onyesom I, Osioma E, Omoghene O. Total antioxidant capacity in serum of Plasmodium falciparum malarial infected patients receiving artemisinin-based combination therapy. Afr J Med Med Sci 2012;2(02):1-3

19 Tuerk MJ, Fazel N. Zinc deficiency. Curr Opin Gastroenterol 2009; 25(02):136-143

20 Owusu-Agyei S, Newton S, Mahama E, et al. Impact of vitamin A with zinc supplementation on malaria morbidity in Ghana. Nutr J 2013;12:131

21 Veenemans J, Milligan P, Prentice AM, et al. Effect of supplementation with zinc and other micronutrients on malaria in Tanzanian children: a randomised trial. PLoS Med 2011;8(11):e1001125

22 Okoli CA, Solomon M, Okoli AC. Serum zinc and copper levels in children with Plasmodium falciparum infection in Nigeria. Int $\mathrm{J}$ Biochem Res 2014;4(04):322-332

23 Saad AA, Doka YA, Osman SM, Magzoub M, Ali NI, Adam I. Zinc, copper and C-reactive protein in children with severe Plasmodium falciparum malaria in an area of unstable malaria transmission in Eastern Sudan. J Trop Pediatr 2013;59(02):150-153

24 Higgins P, Dawson J, Walters M. The potential for xanthine oxidase inhibition in the prevention and treatment of cardiovascular and cerebrovascular disease. Cardiovasc Psychiatry Neurol 2009; 2009:282059

25 El Ridi R, Tallima H; RashikaEl Ridi and HatemTallima. Physiological functions and pathogenic potential of uric acid: a review. J Adv Res 2017;8(05):487-493

26 Lopera-Mesa TM, Mita-Mendoza NK, van de Hoef DL, et al. Plasma uric acid levels correlate with inflammation and disease severity in Malian children with Plasmodium falciparum malaria. PLoS One 2012;7(10):e46424 